\title{
DINAMICA EFECTIVULUI NUMERIC AL BACTERIILOR AMONIFICATOARE ȘI DENITRIFICATOARE ÎN SECTORUL INFERIOR AI RÂULUI PRUT ÎN PERIOADA a. 2015-2019
}

\author{
Igor Șubernețkii, Maria Negru \\ Institutul de Zoologie, e-mail: i.subernetkii@mail.ru
}

\section{Rezumat}

În această lucrare este reflectată dinamica sezonieră și spațială a numărului de microorganisme din ciclul azotului (amonificatori și denitrificatori) în zonele inferioare ale râului Prut.

Cuvinte-cheie: microorganisme acvatice, densitate, amonificatori, denitrificatori. https://doi.org/10.53937/9789975151979.17

\section{Abstract}

This paper reflects the seasonal and spatial dynamics of the number of microorganisms of the nitrogen cycle (ammonifiers and denitrifiers) in the lower areas of the Prut River.

Keywords: aquatic microorganisms, density, ammonifiers, denitrifiers.

nual în diferite sectoare ale râului.S-a efectuat o comparație a rezultatelor obținute de noi în anii precedenți 2011-2014.

\section{REZULTATELE OBȚINUTE}

Printre bacteriile implicate în circuitul azotului, bacteriile amonificatorilor sunt cele mai bine reprezentate numeric. Ele variază între sute și câteva mii de unități formatoare de colonii $/ \mathrm{ml}$ (UFC) cu media de 1,83 $\pm 0,53 \mathrm{mii}(\mathrm{UFC}) / \mathrm{ml}$. (la $\mathrm{p}=0,95) . S-a$ constatat o tendință clar pronunțată de majorarea numărului de amonificatori în sezonul de vară, ce se explică prin creșterea temperaturii apei (Fig. 1).

Distribuția spațială a bacteriilor amonificatoare în r. Prut (mediu pentru sezonul de vegetație) se caracterizează printr-o creștere a numărului acestora de la barajul rezervorului Costești-Stânca până la gura râului (stația Giurgiulești), care, în opinia noastră, este asociată cu nivelul de poluare (Fig. 2).

S-a constatat că efectivul numeric al amonificatorilor este foarte apropiat de cel al bacteriilor saprofite (Fig. 3), ceea ce indică faptul că bacteriile amonificatoare sunt de origine saprofită.

Bacteriile denitrificatoare joacă un rol final foarte important în ciclul de transformare a azotului în ecosistemul acvatic. Cele mai importante condiții pentru acest proces de transformare a compușilor de azot sunt prezența nitraților sau nitriților în mediu, o cantitate suficientă de substanțe organice, o concentrație scăzută a oxi- 


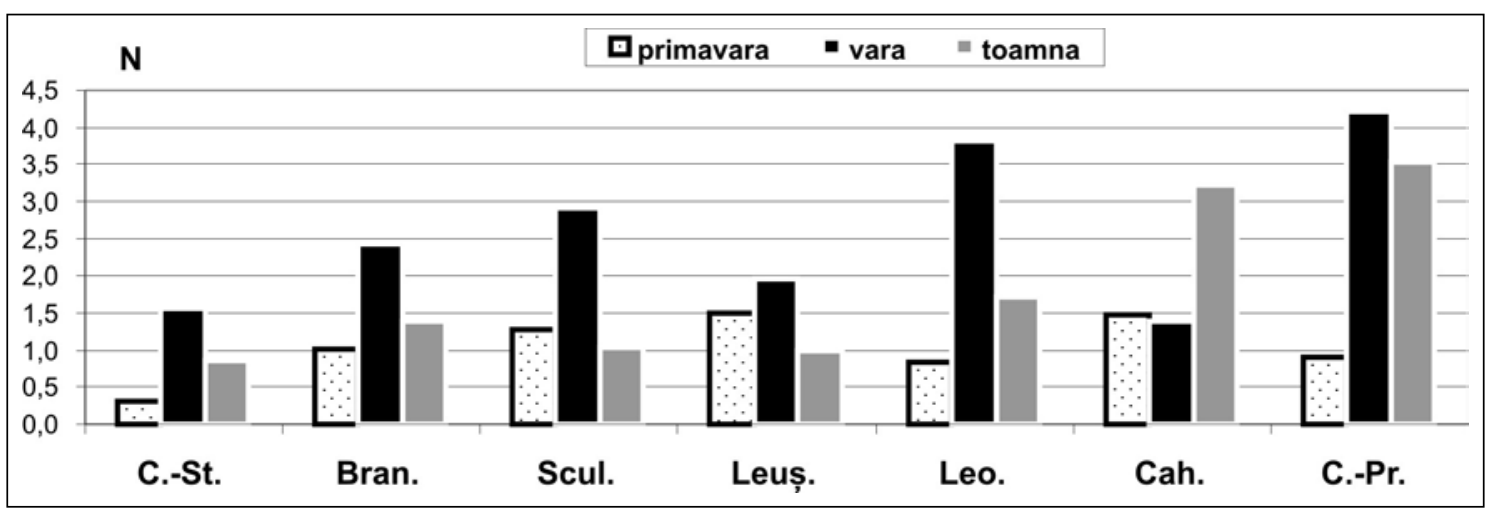

Fig. 1. Densitatea sezonieră (UFC, mii/ml) a microorganismelor amonificatoare în r. Prut (media pe 2015-2019). C.-St. - Costești-Stânca; Bran. - Braniște; Scul. - Sculeni; Leu. - Leușeni; Leo. - Leova; Cah. - Cahul; C.-Pr. - Cîșlița-Prut; Giurg. - Giurgiulești.

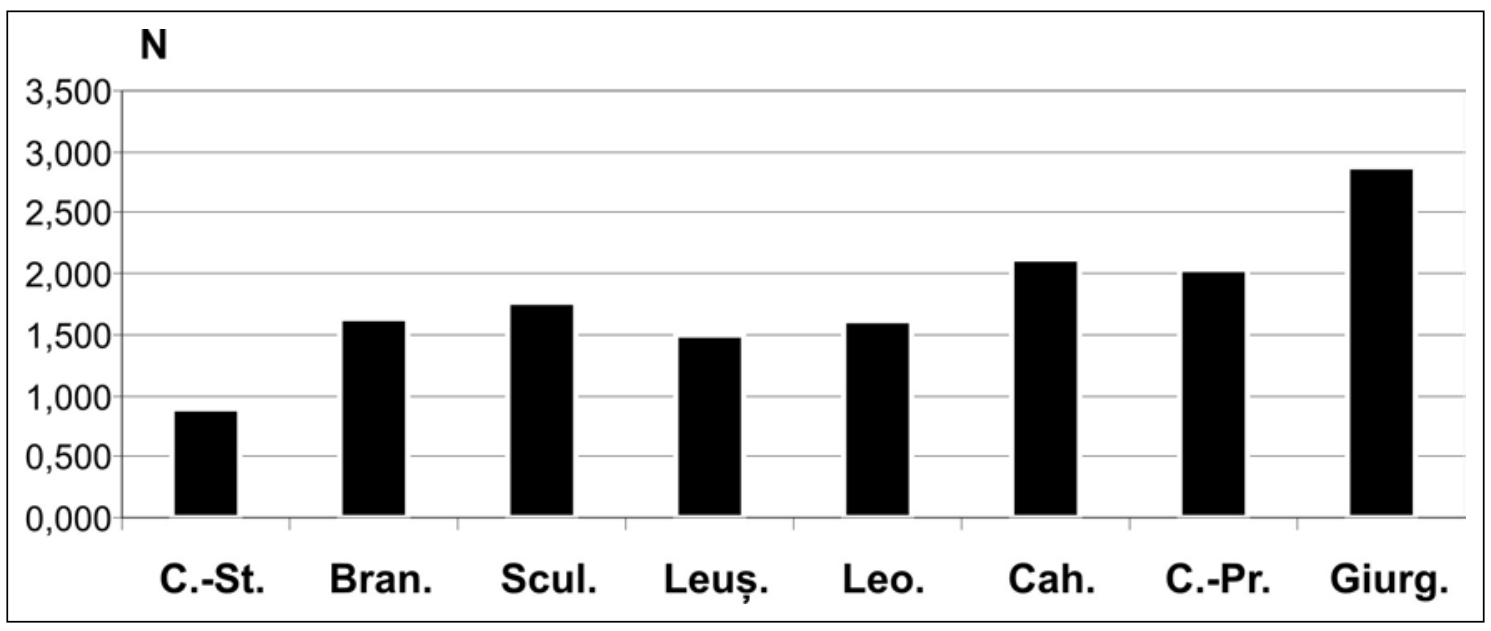

Fig. 2. Distribuția bacteriilor amonificatoare (UFC, mii / ml), media pentru perioada de vegetație, în r.Prut. (vezi notația din fig. 1).

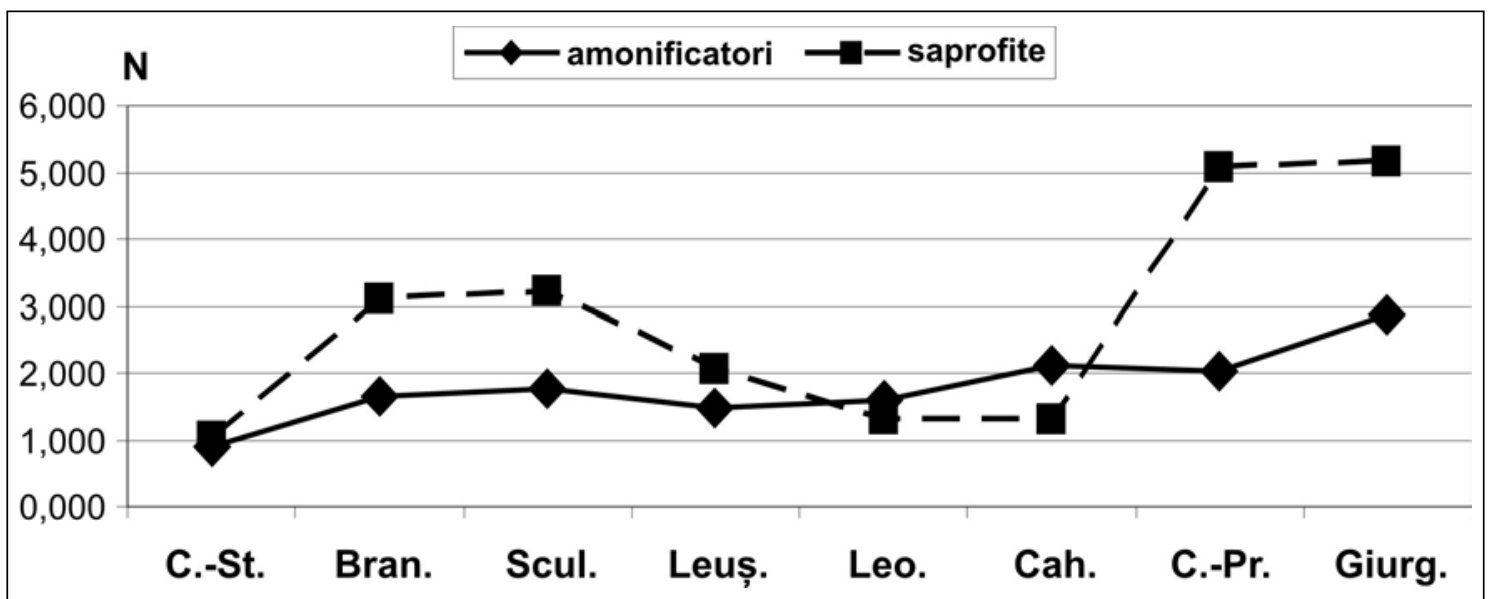

Fig. 3. Dinamica efectivului numeric al amonificatorilor (Nam.) și cel al bacteriilor saprofite (Nsapr) în perioada de vegetație (media pentru 2015-2019), r. Prut (vezi notația din fig. 1).

genului dizolvat și, în cele din urmă, o temperatură optimă de $22 \mathrm{C}$. Condițiile de mai sus nu sunt întotdeauna prezente în ecosistemul studiat de acea efectivul numeric al acestor bacteria este mic și foarte variabil: 0,065 - 1,91 mii UFC/ ml. (Fig. 4), cu media, de 0,15 $\pm 0,03 \mathrm{mii} \mathrm{UFC} / \mathrm{ml}$.
Densitatea numerică a bacteriilor denitrificatoare depinde de temperaturile apei. Anume în sezonul de vară s-au atestat cele mai multe bacterii iar în sezonul de toamnă, numărul lor este fie semnificativ mai mic (Fig.4), fiind aproape egal cu cel de primăvară. 


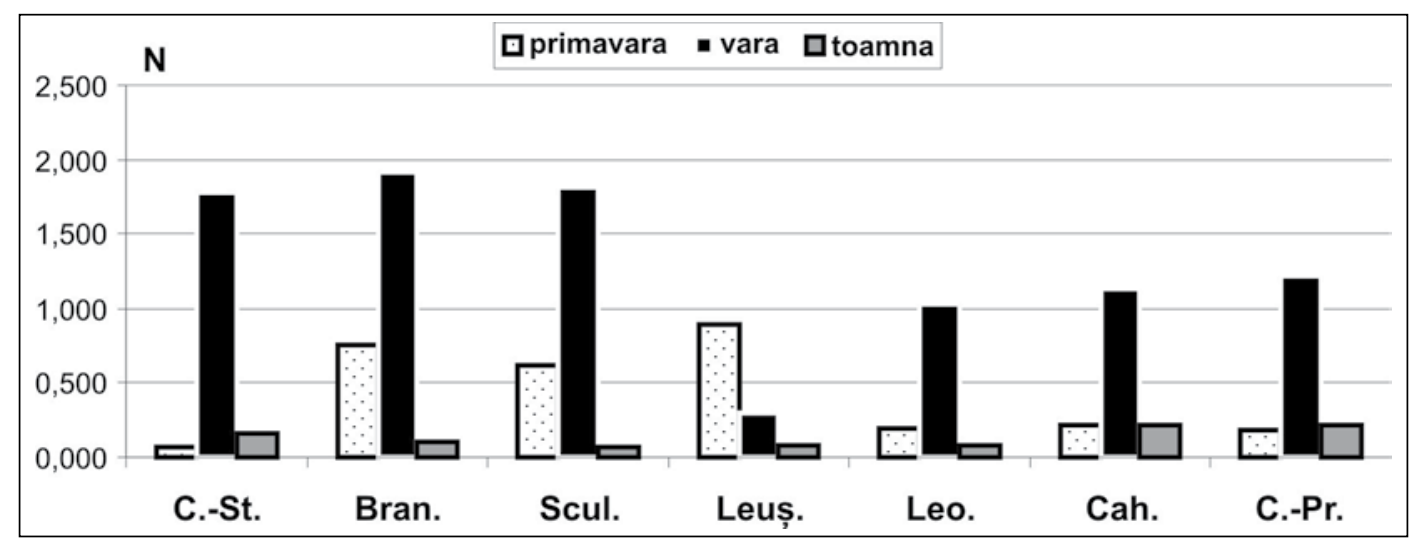

Fig. 4. Dinamica sezonieră a bacteriilor denitrificatoare (UFC mii/ml) în r. Prut, media pentru anii 2015-2019 (vezi notația din fig. 1).

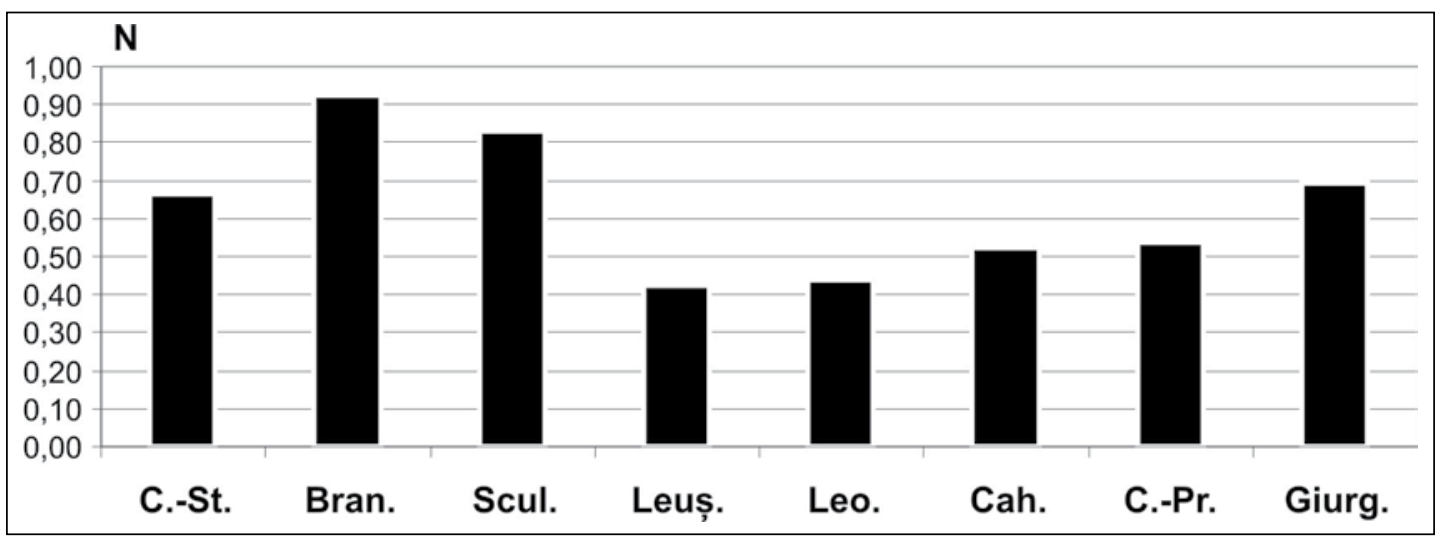

Fig. 5. Distribuția bacteriilor denitrificatoare (UFC mii / ml) de-a lungul r. Prut (vezi notația din fig. 1).

În plus, distribuția spațială a bacteriilor denitrificatoare (medii pentru sezonul de vegetație) sunt, de asemenea, mai nivelate (Fig. 5).

Prin comparație cu determinările efectuate de noi în anii 2011-2014, valorile numerice a amonificatorilor și denitrificatorilor sunt semnificativ diferite. Astfel analiza dinamicii dezvoltării cantitative a bacteriilor amonificatoare în retrospectivă indică faptul că, comparativ cu perioada anterioară, modificările sunt foarte nesemnificative: 1,63 \pm 0,54 UFC mii. / ml în 2011-2014 și 1,83 \pm 0,53 UFC mii / ml. în 2015-2019. Totodată valorile numerice a denitrificatorilor în diferite perioade de investigație sunt semnificativ diferite. Astfel efectivul numeric a denitrificatorilor în perioada anilor 2011-2014 în mediu se cifra cu 0,49+0,21iar în 2015-2019 - 0,15 +0,03 UFC mii/mlîn .

\section{CONCLUZII}

1. În cenoza microbiană a râului. în perioada examinată, s-au produs anumite modificări, dar nu cardinale, în indicatorii cantitativi ai dezvoltării bacteriilor amonificatoare și denitrificatoare.
2. Pentru ambele grupuri de microorganisme, există o dinamică sezonieră pronunțată a dezvoltării cantitative.

3. Dinamica spațială a microorganismelor amonificastoare este determinată de nivelul de poluare a sectoarelorelor râului.

Lucrarea este realizată în cadrul proiectului 20.80009.7007.06 "Determinarea schimbărilor mediului acvatic, evaluarea migrației și impactului poluanților, stabilirea legităților funcționării hidrobiocenozelor și prevenirea consecințelor nefaste asupra ecosistemelor" (Programul de Stat 2020-2023) și a proiectelor BSB 27 și BSB 165 finanțate de Uniunea Europeană (Programul Operațional Comun "Bazinul Mării Negre 2014-2020”).

\section{REFERINȚE}

1. Monitoringul calității apei și evaluării stării ecologice a ecosistemelor acvatice Îndrumar metodic. Chișinău: 2015, 84 p.

2. Ghid de prelevare de probe hidrochimice și hidrobiologice. Chișinău: 2015, 64p. 